\title{
Breeding and feeding biology of the Gurney's Hawk Geranoaetus poecilochrous in the paramo of Antisana, Ecuador
}

\author{
Tjitte de Vries ${ }^{1}$, José Cabot ${ }^{2}$, Mónica Coello ${ }^{1}$ y Diego Alarcón ${ }^{1}$ \\ ${ }^{1}$ Escuela de Ciencias Biológicas, Pontificia Universidad Católica del Ecuador, Apartado 17-01-2184, Quito, Ecuador \\ ${ }^{2}$ Estación Biológica de Doñana, CSIC, Avda Américo Vespucio s/n 41092, Sevilla, España \\ tdevries@puce.edu.ec_Recibido: 2014-05-07; aceptado: 2014-09-12
}

\section{RESUMEN.-}

La biología reproductiva y aspectos relacionados con el aporte de presas y alimentación durante la crianza de los pollos del Gavilán de Gurney, Geranoaetus poecilochrous, fueron estudiados durante 1991 - 1994 y 2007 - 2012 en el páramo del Antisana, Ecuador, a 3800 - 4000 msnm. De 8 territorios bajo control, 6 (75\%) lo constituyeron grupos poliandricos. La nidificación se inicia en casi todos los meses del año, pero el $74 \%$ aconteció en los primeros seis meses del año. El intervalo entre nidificaciones consecutivas de las mismas parejas o grupos poliandricos fue de 6 - 11 meses. La presa principal de la dieta de los pichones fueron conejos, Sylvilagus brasiliensis. La mayoría de las presas para los pichones la aportaron los machos. Los grupos poliandricos se mantuvieron estables durante los cuatro años de estudio, salvo en un territorio en el que se detectaron 3 hembras diferentes en 14 años. Los machos contribuyeron en la construcción del nido, incubación, vigilancia y en aportar presas al nido. En los grupos poliandricos un único macho copuló con la hembra, los otros machos del grupo actuaron como meros "ayudantes". De 15 adultos, en cinco territorios, cuatro $(26.7 \%, 3$ machos, 1 hembra) fueron de la fase clara y $11(73.3 \%, 4$ hembras, 7 machos) de la fase oscura. Detalles de cuatro sonidos (llamadas) son presentados. Los machos ayudantes presentan plumaje subterminal con la parte dorsal rojizo quizás por su condición de subordinados al macho alpha.

PALABRAS CLAVES: Antisana, biología reproductiva, Geranoaetus poecilochrous, páramo, poliandria

\section{ABSTRACT.-}

The breeding and feeding of the Gurney's Hawk Geranoaetus poecilochrous was studied from 19911994 and with further detail from 2007-2012 in the paramo of Antisana, Ecuador, at 3800 - $4400 \mathrm{~m}$ altitude. Of a total of 8 territories at Antisana, $6(75 \%)$ were polyandrous groups and 2 monogamous pairs. Breeding occurred in most months of the year, but $74 \%$ of the 27 clutches registered were found in the first six months of the year. Breeding periods of the same pairs or groups had intervals of 6-11 months. The main prey was rabbits (Sylvilagus brasiliensis). Males brought most food to the young. Polyandrous groups remained stable over the four years of study but in one territory there were three different females over a period of 14 years. Males contributed in nest building, incubation and bringing prey to the young. Only one male was observed copulating with a female, the other males in the group were "helpers at the nest". Of the 15 adults, in five territories, four (26.7\%, 3 males, 1 female) were white bellied (light morph), and 11 (73.3\%, 4 females, 7 males) were dark-bellied birds (dark morph). Details of four different calls are presented.

KEY WORDS: Antisana, breeding biology, Geranoaetus poecilochrous, paramo, polyandry 


\section{INTRODUCTION}

Little is known on the breeding biology of the Gurney's Hawk Geranoaetus poecilochrous. De Macedo 1964 reports on the nesting on top of the bromeliad Puya raimondii in the altiplano of Peru. Lehmann 1945, who seemed to have been the first to publish on the ecology of Gurney's Hawk, apparently confused Buteo poecilochrous with Buteo albicaudatus (Cabot et al. 2006), so clarifying also the comments of del Hoyo 1998: "Somewhat confusing situation in Colombia, where species suspected to be migrant, because no breeding reported, but populations in Bolivia and Peru reported to be resident all year around, leaving source of any migrants to Colombia as a mystery". The distribution pattern of this hawk in Colombia and Ecuador is detailed in Cabot et al. 2010. In northernmost Chile pellets and prey remains correspond to insects and small rodents, but studies on breeding biology are lacking (Jaksic et al., 1991; Jimenez \& Jaksic 1990). Recently, Cabot et al. 2010 have given details on the presence of the Gurney's Hawk in Chile, in the precordilleran plateau of the Atacama desert, at $2000 \mathrm{~m}$ altitude. Cabot, 1991 mentioned for Bolivia "in the geographic zones where Buteo polyosoma and B. poecilochrous coincide, they tend to be segregated" [and] "on the altiplano B. polyosoma is a solitaire winter resident and is found on flat areas. Buteo poecilochrous is a permanent resident, often in pairs and generally associated with rocky hills and mountains with cliffs".

We follow Amaral et al. 2010, using the generic name Geranoaetus, but when citing previous authors we continue to refer to Buteo.

Here we report on the feeding and breeding of the Gurney's Hawk in the paramo of Mount Antisana. With Juan Black we noticed for the first time polyandrous groups in two different territories, but no detailed observations were made at that time on the participation of the extra males (Solís \& Black, 1985).

\section{Study area.-}

Antisana is a snow-capped mountain in the eastern cordillera of the Ecuadorian Andes. The study area was located west of this mountain at an elevation of 3.800-4.400 m, in a grass paramo with bushy areas of Loricaria, Chuquiraga, Diplostephium as well as trees of Gynoxis and patches of Polylepis (Muñoz et al., 1985; Black 1982,). It is an undulated landscape with gullies, lava flows of historic times, with rocky outcrops for roosting and nesting. Free roaming cattle and sheep grazed the area. Annual rainfall is about $700 \mathrm{~mm}$ with precipitation being highest between February - June and October - November, and lowest between July - September. Mid-day air temperatures range from $8^{\circ} \mathrm{C}-14^{\circ} \mathrm{C}$, night temperatures are $-1^{\circ} \mathrm{C}$ in July - August. The weather from October until January is considered mild (normally not so windy). March until June is a rainy period, whereas July - September is known for its snowfall (Black 1982).

Other birds of prey in the area are the common Carunculated Caracara (Phalcoboenus carunculatus) and less frequently the Grey Eagle-buzzard (Geranoaetus melanoleucus), the Cinereus Harrier (Circus cinereus), the Aplomado Falcon (Falco femoralis), the Kestrel (Falco sparverius) and the owls, Great Horned Owl (Bubo virginianus), Short-eared Owl (Asio flammeus) and Barn Owl (Tyto alba); Condors (Vultur gryphus) can be seen daily (de Vries et al. 1983).

\section{MATERIALS AND METHODS}

For our fieldwork we were allowed to use the facilities of the headquarters of EMAP-Q (Empresa Agua Potable Quito) at $4000 \mathrm{~m}$ during 1991-1994, close to the lake Micacocha. Nearby campsites were also established. Nests were observed from hide-watches located some 40 - $50 \mathrm{~m}$ away. Birds were observed from vantage-points with binoculars Zeiss 10x42 and Nikon 8x40, as well as a telescope Bush 20-60x. Studies of Solís and Black 1985 and Coello 1997 were undertaken close to Micacocha (La Mica) and the western flank of Mount Antisana, whereas Alarcón 2012 also concentrated his observations at the territory of La Mica, but extending the study area, including the territory at La Virgen (Figures 1, 2 and 3). Data on 
biomass were based on Solís and Black 1985 Sound recordings were made with a Marantz and Coello 1997: rabbit 425 g, rodent 30 g, PMD671 recorder and a directional microphone bird $390 \mathrm{~g}$, fish $250 \mathrm{~g}$, not identified $30 \mathrm{~g}$. (Sennheiser ME-80).

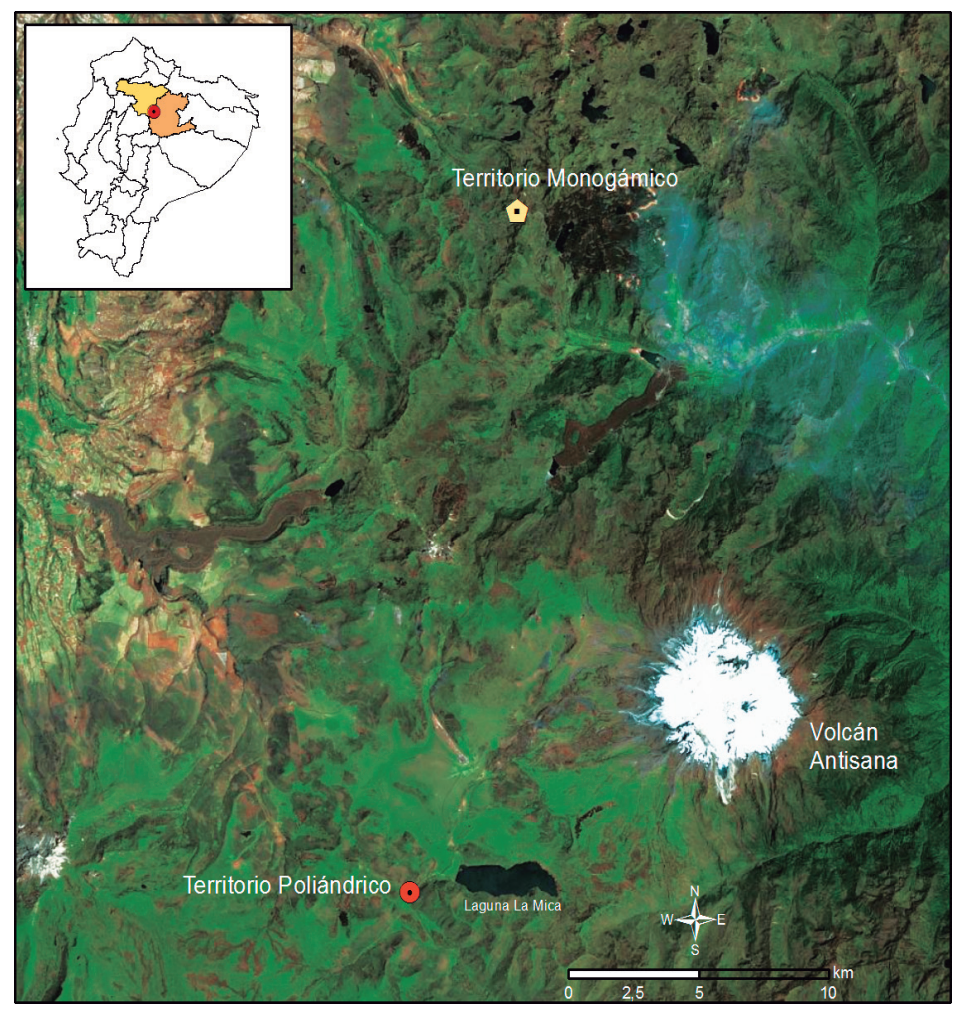

Figure 1. Territories of Micacocha (La Mica, Desaguadero) and La Virgen, around Mountain Antisana.

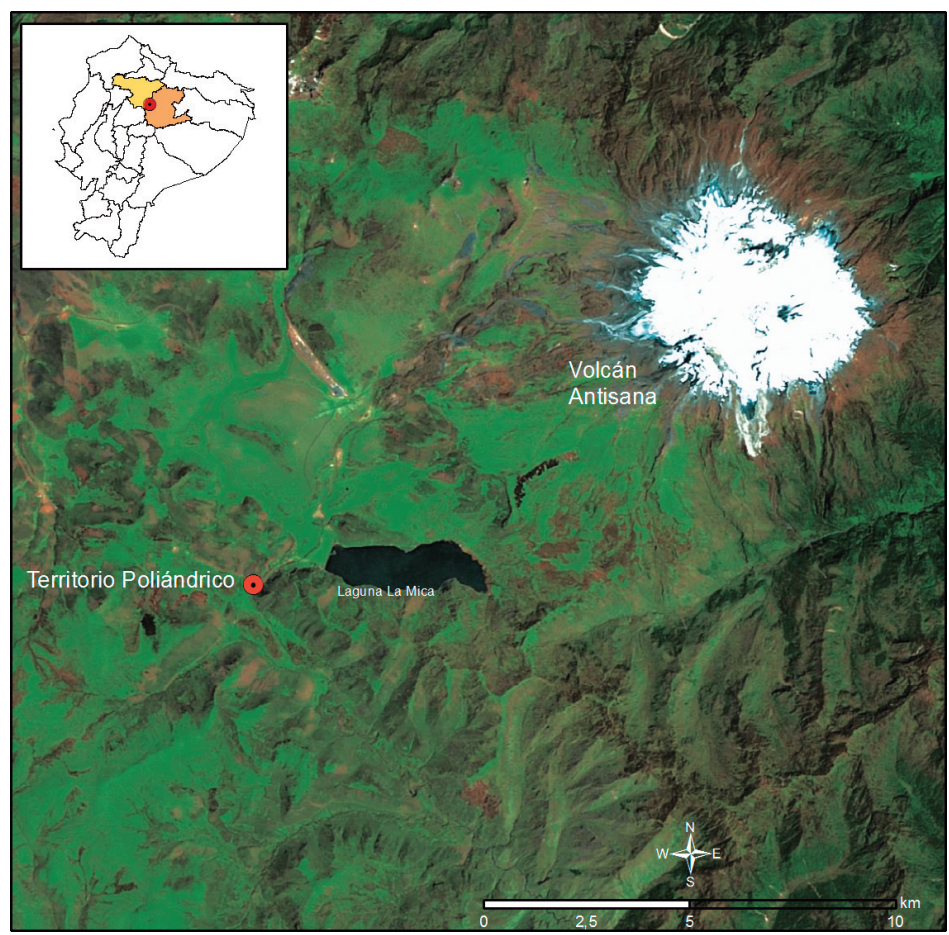

Figure 2. Territory La Mica, with the lagoon of Micacocha and the snow-capped Mountain of Antisana. 


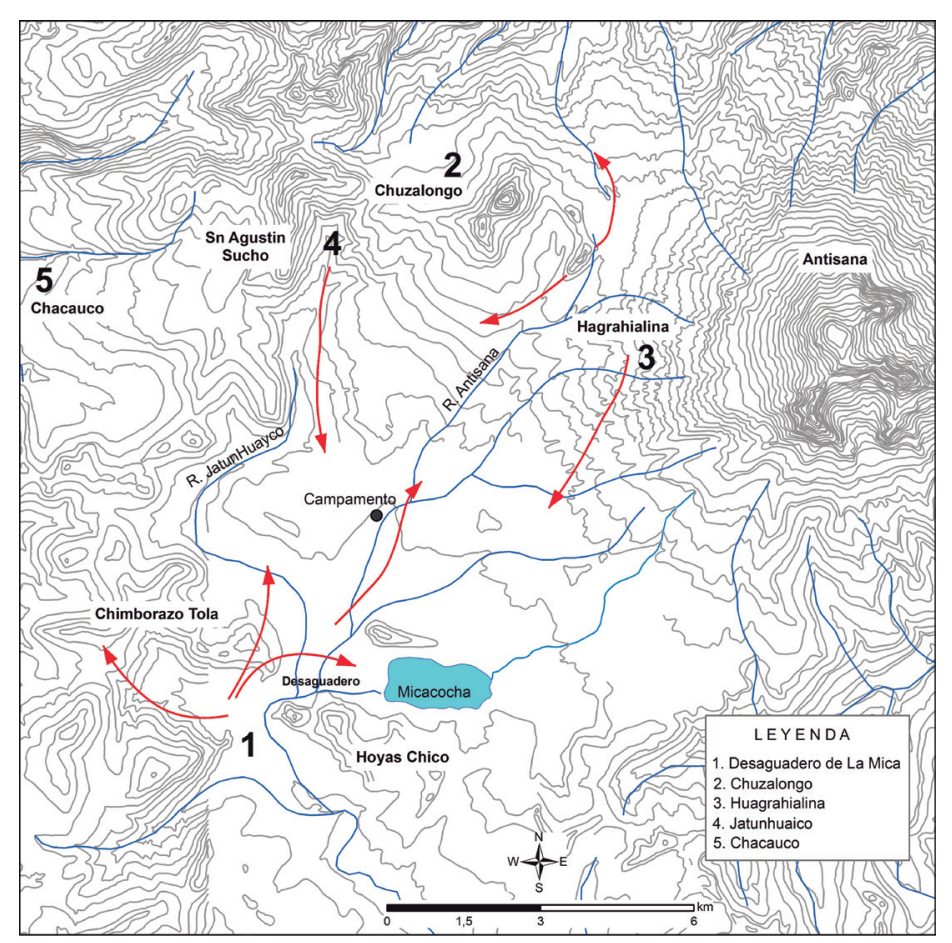

Figure 3. Territories with fly ways at western flank of Antisana.

\section{RESULTS}

\section{Group size.-}

Of a total of eight territories at Antisana, six were polyandrous groups. Three groups were observed with detail to detect composition as to morph, age and sex:

Desaguadero: a female in dark morph predefinitive plumage; two males in dark morph pre-definitive plumage with reddish dorsal patch; and one male in light morph predefinitive plumage.

Saraguasi: a female in dark morph definitive plumage (over six years old; according to Cabot and de Vries 2009); two males in dark morph pre-definitive plumage with reddish dorsal patch; and one male in light morph predefinitive plumage.

Chuzalongo: a female in dark morph definitive plumage (over six years old), one male in dark morph definitive plumage; and one male in light morph definitive plumage.
A pair at Jatunhaicu was composed of a female in dark morph pre-definitive plumage and a male in dark morph definitive plumage.

Changes over time (1980-1994) were observed at Desaguadero (La Mica):

1980: female in dark morph definitive plumage (over six years old), male in dark morph predefinitive plumage, male in dark morph definitive plumage; 1987: female in light morph definitive plumage, male in light morph predefinitive plumage, and male in dark morph definitive plumage; and from 1991-1994: female in dark morph pre-definitive plumage, male in light morph pre-definitive plumage, and two males in dark morph definitive plumage (the different plumages are complex and related to dark or light morph, age and sex, reaching the definitive plumage when six years old; Cabot and de Vries 2009, 7 color plates with 44 photos of the different plumages; Cabot and de Vries 2010, 4 color plates with 40 photos). Some males may have been the same over more than 10 years, but 3 different females were present in 1980, 1987 and the years 1991-1994. The pair at 
La Virgen appeared to remain stable over the years 2007 till 2012 as did the polyandrous group at La Mica in those years.

\section{Breeding.-}

Breeding occurred in most months of the year, but 20 of the 27 clutches were found in the first six months with peaks in March (7 clutches) and June (5 clutches). Nesting in the same territory (and assumed to be the same birds) for Sarahuasi initiated in 5 different months with intervals of 6-11 months (May and December 1991, June 1992, March 1993 and February 1993; for Desaguadero breeding occurred with intervals of 8-10 months (September 1991, June 1992, February and December 1993), whereas for Jatunhuaycu the time was more regular (June 1991, March 1992 unsuccessful, June 1992, March 1993 unsuccessful, June 1993, and February 1994.

During the years 2007-2010 in Desaguadero breeding started in November 2007, November 2008 and October 2009 with an adult female (dark phase, over five years old), an adult male (dark phase) and a second male (light phase), as well as the presence of one juvenile of 2006 and one of 2005. Over the years 2007, 2008 and 2009, every year one juvenile was produced with the same female and the two males. Details of well-known breeding seasons are presented in Figure 4.

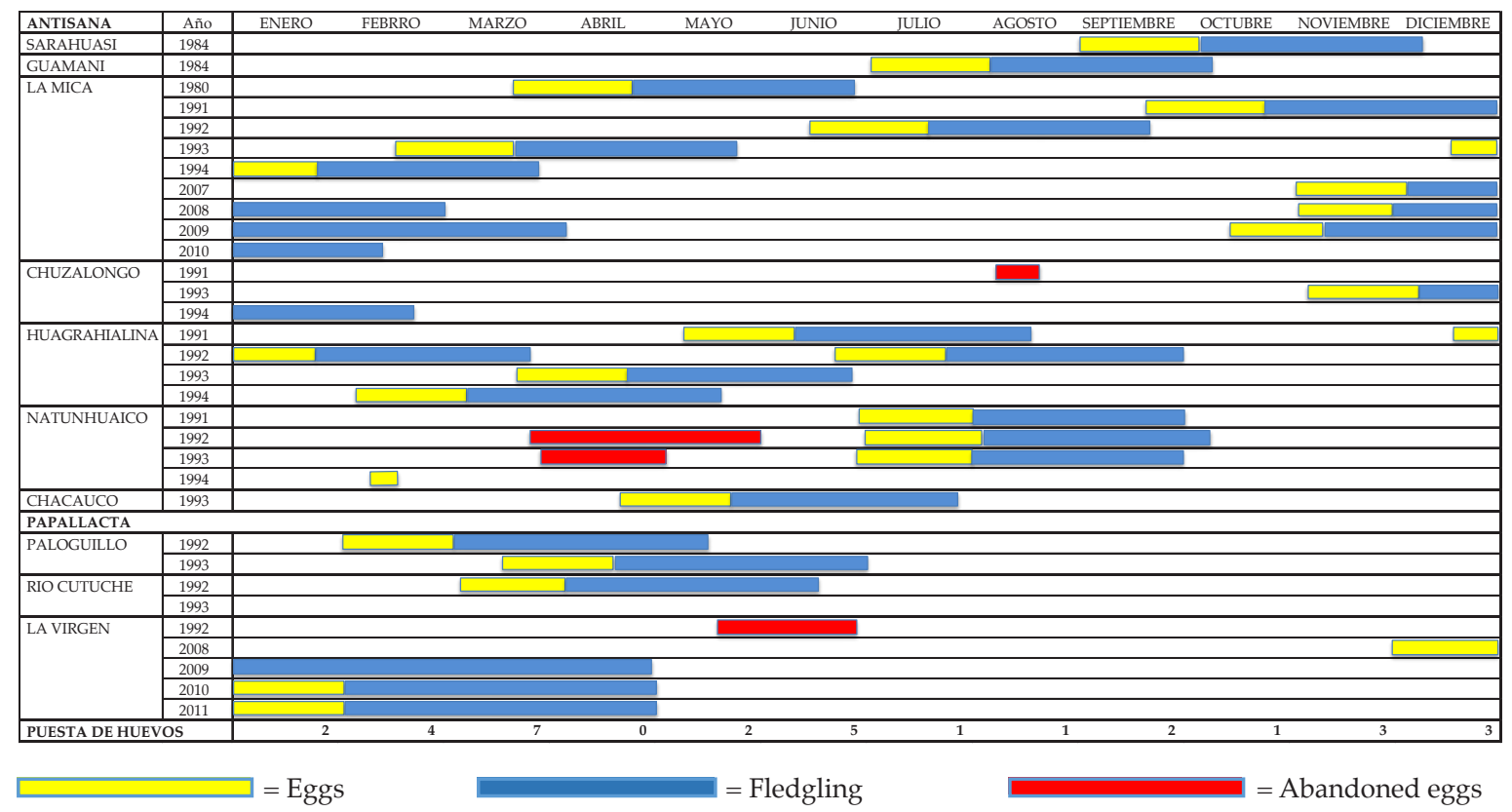

Figure 4. Breeding seasons.

During the breeding period there exists tolerance as well as aggression. An Andean Condor chased a juvenile hawk which had left the nest (Desaguadero) some 14 days earlier, but a male straight away flew to its rescue and on its turn chased the condor, which slowly glided away (23-2-1992). The same juvenile was seen again in the territory, begging for food (1-9-1992), eight months after fledging. On 3-9-1992 the female took prey from the nest (which at the time had an almost fledged young) and flew to the begging juvenile which took the prey immediately. Again, at 13-9-1992 this juvenile flew towards the female and took prey from its talons. When the sole chick from the nest fledged (22-9-1992) both juveniles could be seen sitting together being fed. This is the first time we have seen juveniles from different breeding periods together, both being fed. At 12-1-1993, a year after fledging, this juvenile was still fed in the territory. But in other occasions, parents from Jatunhuaycu drove the juveniles away, actually attacking and chasing in the air, after six months of leaving the nest. 


\section{Nest-building and copulation.-}

All 25 nests were found on rocky outcrops, 1.50-40 $\mathrm{m}$ above the ground, often difficult to reach. The nest was over one meter wide with an inner cup of $40 \times 34 \mathrm{~cm}$ and $7 \mathrm{~cm}$ deep ( $\mathrm{n}=3)$, made of twigs and branches of common bushes as Chuquiraga, Gynoxis, Diplostephium, and Valeriana, with dry grass and mosses for lining.

Copulations were observed, occasionally without any ceremony. We observed the female sitting in a small bush close to the nest and the male arriving and mounting immediately, lasting some 15 seconds, after which the male flew off; in this case after 35 minutes the male returned and again copulation occurred. We have no observations on multiple copulations in polyandrous groups, but two males and the female called and circled around for about 20 minutes after which the female landed in a bush and one of the males landed immediately on the female's back, copulating for 15 seconds. Seven minutes later the same male copulated again (pers. com. S. Struve). In other occasions birds may circle around with ascending and descending flights, sometimes forming an 8 in the air, the male closely following the female, and as she lands the male descends besides her and copulation follows. Copulations were observed during the whole breeding season (with eggs and young in the nest). During the courtship the male brings prey to the female. Only one male of the polyandrous group at la Mica during all three seasons (2007-2010) copulated with the female.

\section{Incubation.-}

Little information on egg-size exists. Our data of $62.2 \times 47.5$ (ranges 60.4-64.0 $\times 45.6-49.0 ; n=6$ ) concur with the size $61.9 \times 47.0(n=2)$ given by Solís \& Black, 1985.
Most incubating in the monogamous pair was undertaken by the female $(84.1 \% ; 74 \mathrm{hrs}$ of observation), whereas in a polyandrous group the female brooded $38.6 \%$ of the time, and the three males, 39.1, 22.3 and 0.0 percent, respectively (17 hrs of observation). The female of the pair did $12.2 \%$ nest guarding (the male $87.8 \%$ ), whereas the polyandrous female guarded $22.4 \%$ and the three males $77.6 \%(15.0,9.9$, and $52.7 \%$, respectively) (details in Coello 1997).

Alarcón 2012 analyzed the activity with more detail, distinguishing six different activities: nest care, hunting, territory defense, nest guarding (vigilance), feeding and activity not known. The monogamous pair shows clearly that in all three seasons the female does most of the incubation, whereas the male does most of the hunting. Unknown activity is far more performed by the male and it refers to being away from the observation spot, close to the nest where the female almost always could be seen. The polyandrous group shows that both males incubate, but still the female takes most of the share. Both males hunt and do most of the defense of the territory and both males help in feeding the chick. The second male is more time away from the nest, out of sight (unknown activity).

\section{Prey brought to the nest.-}

Prey brought to the nest of a monogamous pair at Jatunhaico during 51 hours of observation (8 days, September 1991) amounted to 15 prey items, including rabbits, rodents and birds (Table 1) with a total of $2785 \mathrm{~g}$ of biomass, $76.3 \%$ was rabbit, all brought by the female. 
Table 1. Prey brought to the nest at Jatunhuaico during 51 hours (September 1991).

\begin{tabular}{|c|c|c|c|c|c|c|}
\hline \multirow[b]{2}{*}{ PREY } & \multicolumn{2}{|c|}{ FEMALE } & \multicolumn{2}{|c|}{ MALE } & \multicolumn{2}{|c|}{ TOTAL } \\
\hline & $\mathrm{N}$ & $\begin{array}{c}\% \\
\text { Biomass }\end{array}$ & $\mathrm{N}$ & $\begin{array}{c}\% \\
\text { Biomass }\end{array}$ & $\mathrm{N}$ & $\begin{array}{c}\% \\
\text { Biomass }\end{array}$ \\
\hline $\begin{array}{l}\text { Sylvilagus } \\
\text { brasiliensis }\end{array}$ & 5 & 76.30 & 0 & & 5 & 76.30 \\
\hline Thomasomys & 0 & & 4 & 4.30 & 4 & 4.30 \\
\hline Aves & 0 & & 1 & 14.00 & 1 & 14.00 \\
\hline Salmo sp. & 0 & & 0 & & 0 & \\
\hline Not identified & 0 & & 5 & 5.40 & 5 & 5.40 \\
\hline TOTAL PREY & 5.00 & & 10.00 & & 15.00 & \\
\hline PREY/HOUR & 0.09 & & 0.20 & & 0.29 & \\
\hline BIOMASS (g) & 2125.00 & & 660.00 & & 2785.00 & \\
\hline$\%$ BIOMASS & 76.30 & & 23.70 & & 100 & \\
\hline
\end{tabular}

At Huagrahialina during 60 hours of observation all four adults; interestingly, the female brought (8 days, September 1992), a polyandrous group also fish (trout). Here the female contributed with consisting of a female with three males brought $29 \%$ of the biomass, the rest was brought by the 21 prey items, with rabbits and rodents hunted by three males; total biomass was $3405 \mathrm{~g}$ (Table 2).

Table 2. Prey brought to the nest at Huagrahialina during 60 hours (September 1992).

\begin{tabular}{|c|c|c|c|c|c|c|c|c|c|c|}
\hline PREY & \multicolumn{2}{|c|}{ FEMALE } & \multicolumn{2}{|c|}{ MALE 1} & \multicolumn{2}{|c|}{ MALE 2} & \multicolumn{2}{|c|}{ MALE 3} & \multicolumn{2}{|c|}{ TOTAL } \\
\hline Thomasomys & 1 & 0.90 & 2 & 1.80 & 3 & 2.60 & 5 & 4.40 & 11 & 9.70 \\
\hline Salmo sp. & 2 & 11.50 & 0 & & & & 0 & & 2 & 14.70 \\
\hline $\begin{array}{l}\text { Not } \\
\text { identified }\end{array}$ & 1 & 0.90 & 0 & & 1 & 0.90 & 0 & & 2 & 1.80 \\
\hline $\begin{array}{l}\text { TOTAL } \\
\text { PREY }\end{array}$ & 5.00 & & 4.00 & & 6.00 & & 6.00 & & 21.00 & \\
\hline$\%$ BIOMASS & 28.92 & & 25.69 & & 28.49 & & 16.89 & & 100.00 & \\
\hline
\end{tabular}


At La Mica, also a polyandrous group with three males, one male did not bring food but rather took prey remains from the nest; however, this male later contributed with prey when the young fledged. The other two males brought one rodent and 11 rabbits (the female contributed with six rabbits) and therefore males contributed with most of the biomass (65.5\%; Table 3).

Table 3. Prey brought to the nest of Desaguadero (La Mica) during 77 hours (September 1992).

\begin{tabular}{|c|c|c|c|c|c|c|c|c|c|c|}
\hline \multirow[b]{2}{*}{ PREY } & \multicolumn{2}{|c|}{ FEMALE } & \multicolumn{2}{|c|}{ MALE 1} & \multicolumn{2}{|c|}{ MALE 2} & \multicolumn{2}{|c|}{ MALE 3} & \multicolumn{2}{|c|}{ TOTAL } \\
\hline & $\mathrm{N}$ & $\begin{array}{c}\% \\
\text { Biomass }\end{array}$ & $\mathrm{N}$ & $\begin{array}{c}\% \\
\text { Biomass }\end{array}$ & $\mathrm{N}$ & $\begin{array}{c}\% \\
\text { Biomass }\end{array}$ & $\mathrm{N}$ & $\begin{array}{c}\% \\
\text { Biomass }\end{array}$ & $\mathrm{N}$ & $\begin{array}{c}\% \\
\text { Biomass }\end{array}$ \\
\hline S. brasiliensis & 6 & 33 & 4 & 22 & 7 & 38.50 & 0 & & 17 & 93.40 \\
\hline Thomasomys & 0 & & 0 & & 1 & 0.40 & 0 & & 1 & 0.40 \\
\hline Aves & 0 & & 0 & & 0 & & 0 & & 0 & \\
\hline Salmo sp. & 0 & & 0 & & 0 & & 0 & & 0 & \\
\hline $\begin{array}{l}\text { Not } \\
\text { identified }\end{array}$ & 4 & 1.60 & 5 & 1.90 & 7 & 2.70 & 0 & & 16 & 6.20 \\
\hline $\begin{array}{l}\text { TOTAL } \\
\text { PREY }\end{array}$ & 10.00 & & 9.00 & & 15.00 & & 0 & & 34.00 & \\
\hline PREY/HOUR & 0.13 & & 0.12 & & 0.19 & & & & 0.44 & \\
\hline $\begin{array}{l}\text { BIOMASS } \\
\text { (g) }\end{array}$ & 2670.00 & & 1850.00 & & 3215.00 & & 0 & & 7735.00 & \\
\hline$\%$ BIOMASS & 34.50 & & 23.90 & & 41.60 & & & & 100.00 & \\
\hline
\end{tabular}

The three territories combined indicate that most of the prey was brought by the males (50 of a total of 70), also in biomass the seven males contributed with $61 \%$ (versus $39 \%$ of the three females; total biomass $14805 \mathrm{~g}$; Coello 1997). Rabbits formed $83.25 \%$ of the biomass, the rest were rodents (Thomasomys and/or Akodon), birds (snipe, Gallinago) and fish (trout, Salmo).

Prey brought to chicks at the nest and preys brought to fledged juveniles (at the nest or at roosts nearby) were not different; in both cases rabbits formed the main prey. The frequency of prey (numbers per hour) decreased however, 0.44 to $0.22,0.35$ to 0.26 , and 0.29 to 0.15 , respectively, for the 3 territories (Coello 1997). No clear differentiation in prey specialization, either for sex or between the males, was noted in any site.

The data obtained by Alarcón (2012) almost two decades later at La Mica, with a polyandrous group of two males at that time showed a biomass of rabbits of $94.3 \%$. Over the three seasons studied, the female brought 11 of the 36 rabbits and contrasted with hunting only one of the 14 rodents (Table 4 ).

Table 4. Prey brought to the nest during 3 breeding seasons at La Mica.

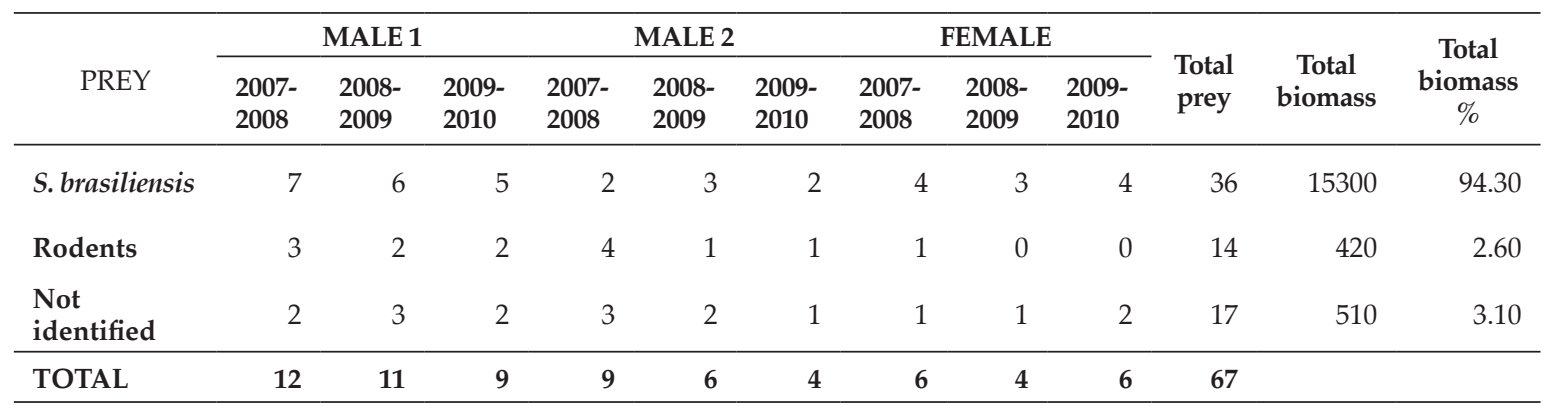


At La Virgen, the monogamous pair, over the three seasons (2009-2011) was almost only living of rabbits ( $98.2 \%$ of biomass). The female brought 10 of the 55 rabbits and four of the six rodents (Table 5).

Table 5. Prey brought to the nest during 3 breeding seasons at La Virgen.

\begin{tabular}{|c|c|c|c|c|c|c|c|c|c|}
\hline \multirow{2}{*}{ PREY } & \multicolumn{3}{|c|}{ MALE } & \multicolumn{3}{|c|}{ FEMALE } & \multirow{2}{*}{$\begin{array}{l}\text { Total } \\
\text { prey }\end{array}$} & \multirow{2}{*}{$\begin{array}{c}\text { Total } \\
\text { biomass }\end{array}$} & \multirow{2}{*}{$\begin{array}{c}\text { Total biomass } \\
\%\end{array}$} \\
\hline & 2009 & 2010 & 2011 & 2009 & 2010 & 2011 & & & \\
\hline S. brasiliensis & 12 & 12 & 17 & 4 & 5 & 5 & 55 & 23375 & 98.20 \\
\hline Not identified & 2 & 1 & 2 & 1 & 1 & 1 & 8 & 240 & 1.00 \\
\hline TOTAL & 14 & 15 & 19 & 7 & 7 & 7 & 69 & & \\
\hline
\end{tabular}

For all groups and years the grand total of prey brought to the nest is: 118 rabbits, 36 rodents, two birds, two fish and 48 unidentified items.

\section{Reproductive costs.-}

Calculated over the same period (12 hrs), polyandrous groups brought more prey biomass compared to the monogamous pair. The group with most prey (Desaguadero) raised one chick, the others (pair and group) 2 chicks each, so prey biomass does not simply relate to the output of number of chicks.

Several young were weighed when near fledging. A single chick, according to the measurements a female, weighed $1350 \mathrm{~g}$, whereas the monogamous chicks had $850 \mathrm{~g}$ (male) and $1000 \mathrm{~g}$ (male), and the 2 chicks of the other group, males, 1000 $\mathrm{g}$ and $1050 \mathrm{~g}$, at the age of fledging. The last mentioned group reared the following breeding period one female (1500 g) of a clutch of 2, one chick died when 3 weeks old. So it seems that either one female or two males can be reared.

Over four years of study (1991-1994), the monogamous pair produced 3 fledglings (2 clutches of 2 eggs failed, whereas 2 other clutches of both 2 eggs were not followed to the final stage, so this pair could have raised 4 more chicks) from 11 eggs, while the polyandrous groups combined, on average, raised 4 fledglings (with the rather dispersed figures of 1, 4, and 7, respectively) and so totaled 12 fledglings out of 17 eggs (maximum 21, as in 4 nests eggs could not be seen and counted and may have had not one but two eggs); reproduction success for the monogamous pair was $3 / 11$ or 0.27 (but could have been $7 / 11$ or 0.63 ), while for polyandrous groups it was $12 / 17$ or 0.70 (but could have been 12 / 21 or 0.57 ).

The polyandrous group at La Mica raised over the 3 seasons (2007-2009), every year a chick and juveniles of years before remained around. The monogamous pair at La Virgen raised also one chick every year over the 3 seasons (20092011), but in 2011 the juvenile died straight after fledging, falling off the cliff, breaking both legs.

\section{Territory size.-}

Territorial boundary disputes were rarely seen, but sometimes alien hawks flew in too close to the range of the nest and were chased off. It seems that groups avoid each other in a flat landscape with natural boundaries of small hills, galleys and rocky outcrops. The areas covered by the different territories fluctuated between some 10-16 km2 (Figure 3). 


\section{Vocalization.-}

Vocalizations in birds of prey are important messages to indicate details on behavior which may be related to the other sex, to individuals of the same species or to other predators.

Details given here on Geranoaetus poecilochrous are interesting as a study is underway to compare different calls of this species to its close relative G. polyosoma, a species living in the habitat of the bush paramo, below $3000 \mathrm{~m}$ and the interandean valley, as well as the subspecies G. polyosoma peruviensis from the coastal parts of Ecuador (Peninsula of Santa Elena) and northern Peru (Buitrón et al. 2010).

As the vocalizations of Buteo hawks are partly genetically fixed but influenced by differences in habitat, open grass paramo or denser bush paramo or open dry forest calls of similar behavior may be compared between the taxa. Few published data exist on the calls of the Gurney Hawk. Brown and Amadon 1968 mention "it is said to call persistently for up to five minutes at a time", for Buteo polyosoma they write "a continous schreeching when its nest is disturbed. A schrill yeak-yeak or kyeah kyeah". Fjeldsa and Krabbe 1990 write under the heading of voice: "a long drawn peeeoh ranging from copious cry to thin whistle, hoarse in juveniles. In display flight harsh hee hee hee" for Buteo poecilochrous. And for B. polyosoma "sometimes calls when hunting. Loud keeowkyow-kyow noted from pair near nest".

The calls of G. poecilochrous can be classified as rythmic repetitives and simple, with a frequency from 1401 - $6027 \mathrm{kHz}$ (Alarcón 2012). Four different calls can be distinguished, related to the following behaviors:

- Attention or warning call, a rather long "kleeeeee". Heard when approaching the nest and also uttered by the female in absence of the male (Figure 5).

- Aggression, exciting or attack call, a very rapidly repeated staccato "ke-ke-ke-ke-ke-". Heard when intruders approach or enter the territory (Figure 6).

- Begging call or submissive call, a repeated "kee", slower than the aggressive call, used by the female at the nest as well as by juveniles begging and receiving prey (Figure 7).

- Arriving or announcing call, a short "keee" made by the male when he arrives at the nest (Figure 8).

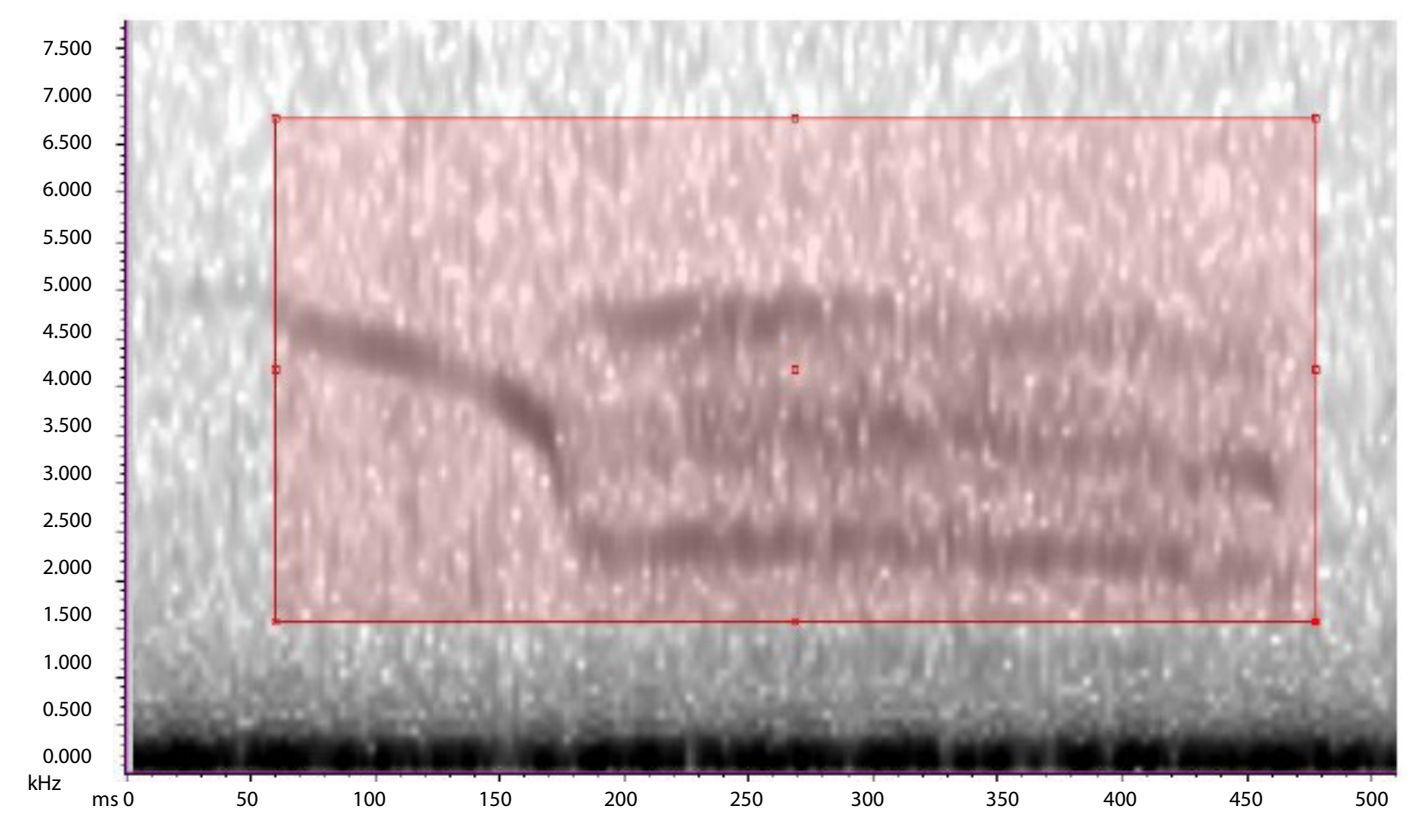

Figure 5. Attention or warning call. 


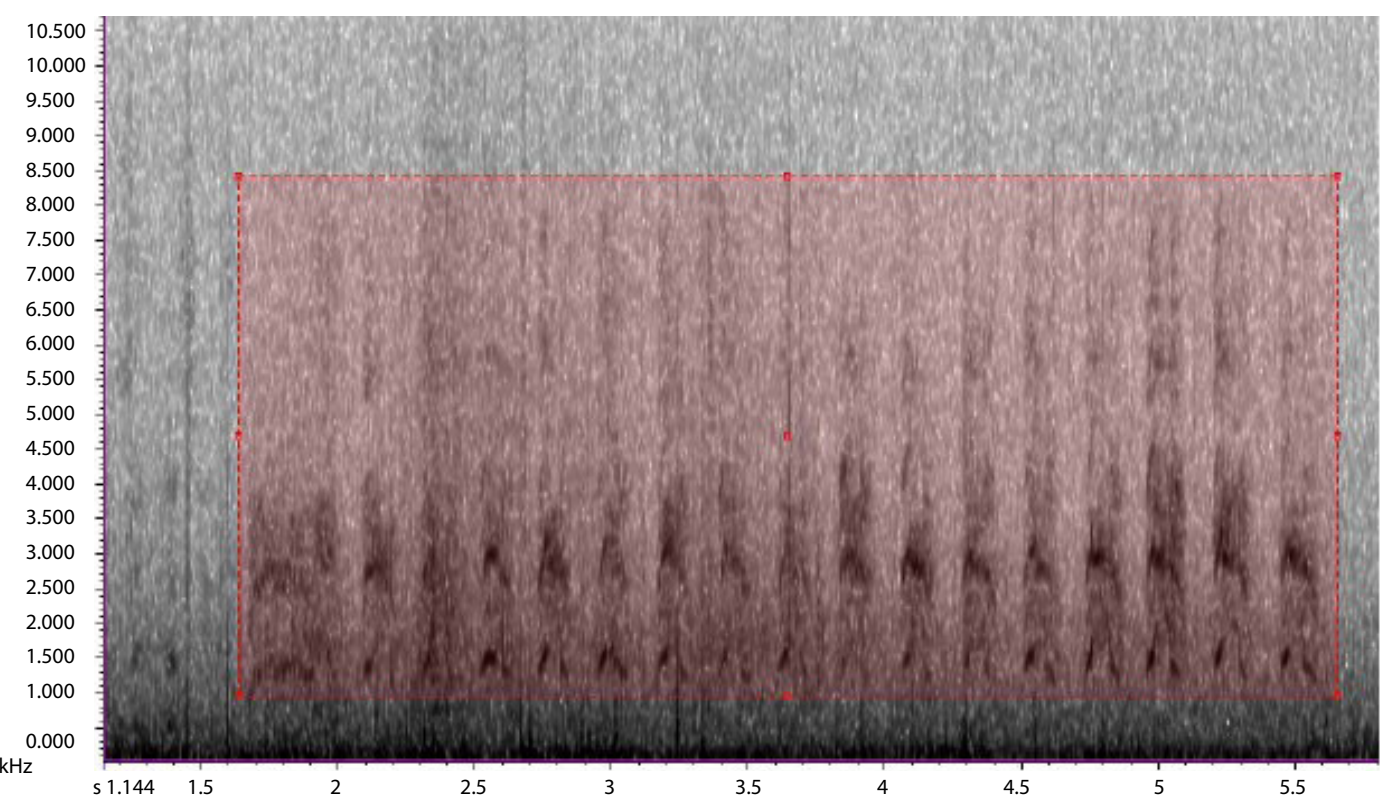

Figure 6. Aggression, exciting or attack call.

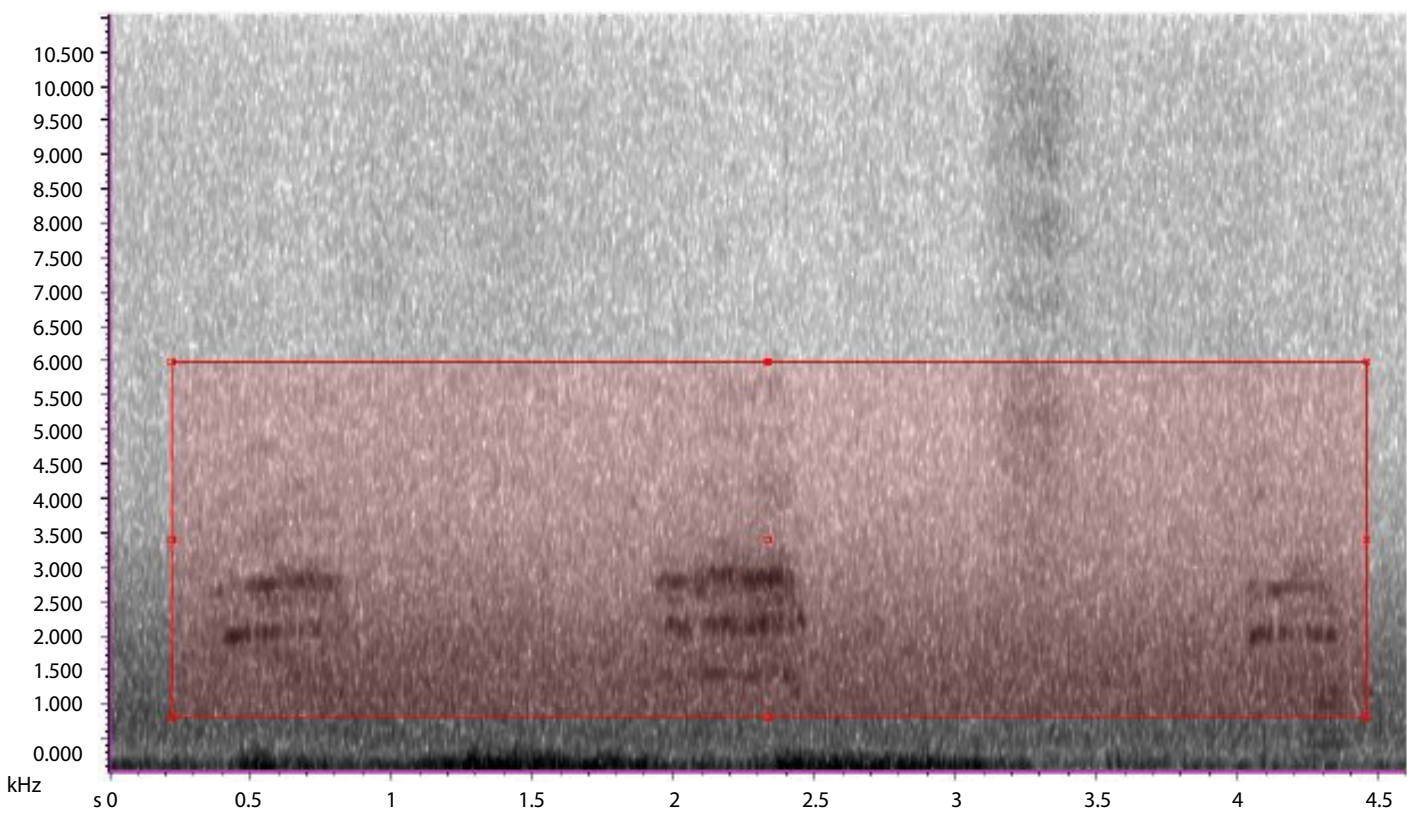

Figure 7. Begging call or submissive call. 


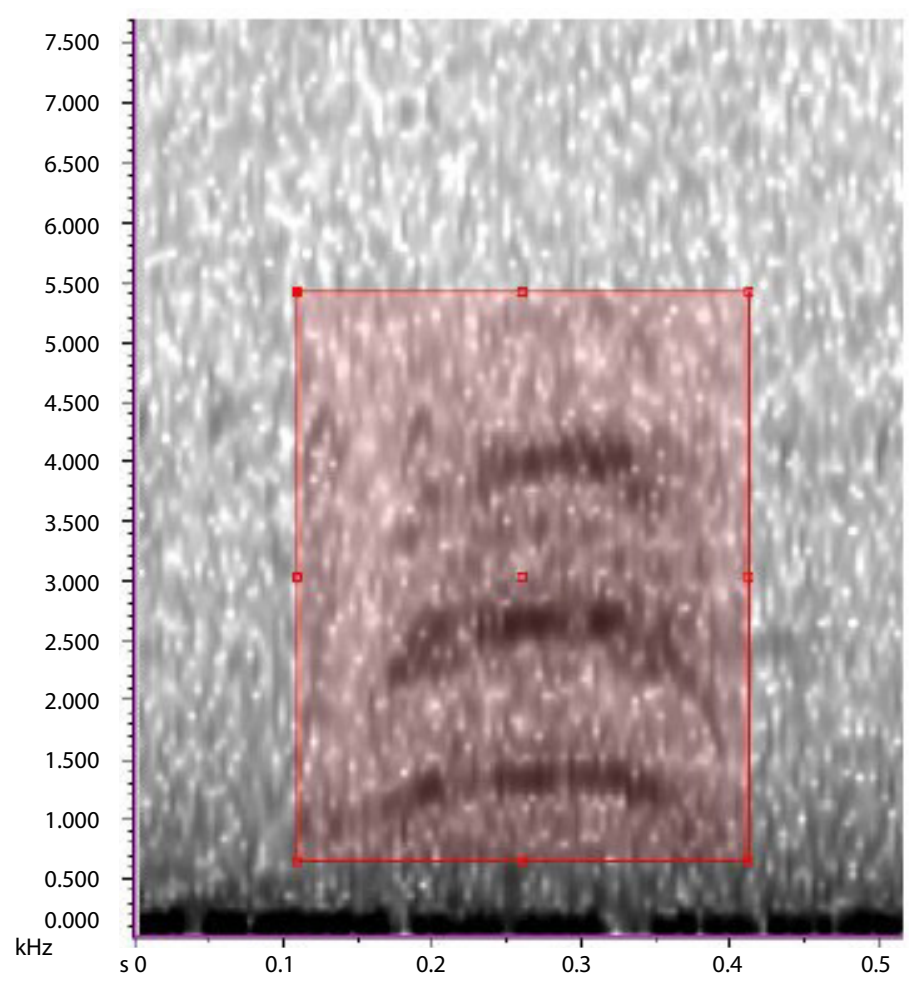

Figure 8. Arriving or announcing call.

\section{DISCUSSION}

Lehmann, 1945 confused Buteo poecilochrous with $B$. albicaudatus when he published on the ecology of Gurney's Hawk, as was clarified by Cabot, de Vries \& Stiles, 2010, at the same time rectifying what Del Hoye et al. 1998 called the "somewhat confusing situation in Colombia".

In northernmost Chile pellets and prey remains collected indicate insects and small mammals (Jaksic et al., 1991; Jiménez and Jaksic 1990,). Cabot, de Vries and Alvarado 2010 mention as prey Fulica sp, as well as Rattus norvegicus, found under the nests in the galley of the river Loa in the Atacama desert in Chile.

Here we demonstrate that in the breeding season at the paramo of Antisana the main prey-item are rabbits, Sylvilagus brasiliensis, and rodents (Thomasomys and/or Akodon) with less than $10 \%$ in biomass.

The speciation and the close relationship between Buteo poecilochrous, B. polyosoma, B. albicaudatus and Geranoaetus melanoleucus was discussed in
Cabot and de Vries 2010 and in Cabot, de Vries and Márquez 2010.

The presence and maintenance of dark and light phased birds (with the complexity of plumage patterns related to age and sex over a period of six years in Buteo poecilochrous and B. polyosoma (Cabot and de Vries 2010, 2003), is not easy to explain.

Cabot and de Vries 2010 comment "the coloration differences between sexes and ages in B. poecilochrous may be related to the coexistence of several individuals within a restricted area and with high food availability". Male helpers at the nest have pre-definitive plumages with a reddish dorsal patch, which may be related to being submissive to the alpha male. Females of the dark morph may breed in a pre-definitive plumage (with reddish breast band) before they reach their definitive plumage. Breeding in subadult plumage does also occur in the Galapagos Hawk when food and space (empty territories) are available, and when apparently adults are lacking (de Vries 2009). 
In skuas also light and dark phases occur and Kjellén 1997 suggests that dark skuas are more efficient kleptoparasites over sea while the light phase is an advantage for hunting over the tundra, with a mosaic pattern of snowcovered areas and open areas with vegetation. At the Andean paramo dark birds may be in an advantage at certain circumstances and under certain climatic conditions with fog and cloudy weather, but light morphs are not at a complete disadvantage with clear skies and snow-covered areas at times of the year. At Antisana, with the majority of dark birds, studies in hunting behavior will have to reveal why such a variety of phases still exists.

\section{Comparison of social groups in Gurney's and Galapagos Hawks.-}

Since Brosset (1963) drew attention to the presence of three hawks at a nest-site of the Galapagos Hawk (Buteo galapagoensis) polyandry in this species has been studied in further detail (DeLay et al. 1996; Faaborg et al. 1995; Faaborg et al. 1980; Faaborg and Patterson1980; de Vries, 1976, 1975, 1973). Faaborg and Bednarz 1990 describe the breeding behavior of two species, the Galapagos Hawk and the Harris Hawk (Parabuteo unicinctus), comparing the ecological factors affecting the development of group breeding, and they concluded that their social systems are widely divergent in composition, stability and function. Later, other raptors were found to be polyandrous as well and Malan et al., 1997 demonstrate in the Pale Chanting Goshawk (Melierax canorus) polyandry to be related to habitat structure, with monogamous pairs being equally successful in other types of habitat. So ecological factors play a definite role.

With Juan Black we noticed for the first time polyandrous groups in Buteo poecilochrous at Antisana in two different territories, but no detailed observations were made of the participation of the extra males (Solís and Black 1985). Four territories were observed during 1991-1994, three of which were occupied by polyandrous groups (two three-male groups and one two-male group), the other being a monogamous pair. During the four years of study the male groups (all in advanced adult plumage, with white tail and a black sub terminal band) remained stable. From 2007 till 2010 the territory at Desaguadero was again observed and over the three breeding seasons a polyandrous group of two males and the female bred every year, and in this territory it was noted that juveniles hang around in the area and are still at times being fed by the adults and so most likely start such a group bond.

In Galapagos, male groups are more numerous. Besides the arid habitat, which is the breeding ground, there is a humid region where nonbreeders survive (i.e., large and high islands). So far in the Gurney's Hawk only polyandrous groups have been found at Antisana in Ecuador (i.e. mountains in the tropic) and gregarious males in the Atacama desert in Chile. Breeding of a pair has been reported in el Altiplano in Peru (de Macedo 1964).

What then makes the habitat of the paramo of Antisana different from the rest of the Andes? In Ecuador, it is the most extensive, open, undulated, swampy area, which may make conditions suitable for non-breeding birds to stay and join breeders. Forming part of members of a group within a territory would give better survival possibilities, not only as it provides hunting grounds, but prey not eaten by chicks which remains at the nest is occasional taken. In other paramos in Ecuador (Chiles, Cayambe, Cotopaxi, Chimborazo) breeding ranges may be smaller and leaving little space for juveniles and non-breeders to be allowed to join. This situation and the possibility of breeding all year around (i.e., tropical conditions, rather than temperate, seasonal) may have led to the social system of breeding in groups and with monogamy also still not completely selected against.

The difference between the social system of the Galapagos Hawk and the Gurney's Hawk is that all males of the Galapagos Hawk copulate with the female and chicks belong to different males. The Gurney's Hawk males and subadults are "helpers at the nest" (just one male six or more years old copulates with the female) and 
juveniles of different years remain in the territory and are being fed. Juveniles of the Galapagos Hawk remain up to three months within the territory and are forced out and have to survive in non-territorial areas.

\section{ACKNOWLEDGEMENTS}

We thank EMAP-Q (Empresa Agua Potable Quito) for providing facilities at their headquarters. The Family Delgado and Mario Pallares for allowing us to work at Hacienda Pinantura, part of which now forms part of the Antisana Reserve and we are grateful to the Ministry of Environment (Ministerio del Ambiente) allowing us to continue investigating. La Pontificia Universidad Católica del Ecuador (PUCE) supported the Project "Ecological studies of Tropical Raptors" over the many years of study. The Frank Chapman Memorial Fund kindly assisted with a grant in the final part of the study of MC. Dr. Craig Farquhar provided funds and equipment and was a good companion in not always fine weather conditions. Luis Eduardo Lopez assisted in many field trips, locating nests and scaling the rocky outcrops. Pablo Sánchez and Gabriela Toscano visited several times the territories in order to determine the breeding periods. Dr. Peter Grant commented on and corrected part of an earlier draft. Cristian Poveda was most helpful in adapting the Figures and Tables. Two anonymous referees contributed in clarifying the text.

We dedicate this paper to the memory of Juan Black (1946-1996), ardent naturalist and concerned to conserve Antisana and Galapagos.

\section{REFERENCES}

Amaral FR, Sheldon FH, Gamouf A, Haring E, Riesing MJ, Silveira LF, Wajntal A. 2010. Priority of Geranoaetus Kaup, 1844 over Tachytriorchis Kaup, 1844 (Aves: Accipitridae) based on the first reviser principle. Zootaxa, 2534:67-68.

Alarcón D. 2012. Biología reproductiva y descripción de la bioacústica del Gavilán de Gurney, Buteo poecilochrous poecilochrous
(Accipitridae, Falconiformes) en el Páramo del Antisana y el Páramo de la Vírgen, Ecuador. Tesis de Licenciatura, PUCE, Quito, Ecuador.

Bednarz J, Ligon D. 1988. A study of the ecological bases of co-operative breeding in the Harris Hawk. Ecology 69 (4): 1176-1187.

Black J. 1982. Los páramos del Antisana. Revista Geográfica Quito 17:25-52.

Brosset A. 1963. Le Comportement de la Buse des Galapagos Buteo galapagoensis. Alauda 31 (1): 5-21.

Brown L, Amadon D. 1968. Eagles, hawks and falcons of the world. McGraw-Hill, New York.

Buitrón G, Cabot J, de Vries T. 2010. Patrón preliminar de distribución del buzardo dorsirojo Buteo polyosoma en Ecuador. Pp 137141. In: Hernández VJ, Muñiz R, Cabot J y de Vries T (Eds.). Aves Rapaces y Conservación. Una perspectiva iberoamericana. Tundra Ediciones, Valencia, España.

Cabot J, de Vries T. 2010a. La diversificación de Buteo polyosoma y Buteo poecilochrous con respecto a Buteo albicaudatus ocurrió en los Andes de Colombia en el último período postglacial. Pp. 143-144. In: Hernández VJ, Muñiz R, Cabot J y de Vries T (Eds.). Aves Rapaces y Conservación. Una perspectiva iberoamericana. Tundra Ediciones, Valencia, España.

Cabot J, de Vries T.2010b. Taxonomic and plumage relationship between Red-backed Buzzards Buteo polyosoma and Buteo poecilochrous. Pp. 163-179. In: Hernández VJ, Muñiz R, Cabot J y de Vries T (Eds.). Aves Rapaces y Conservación. Una perspectiva iberoamericana. Tundra Ediciones, Valencia, España.

Cabot J, de Vries T, Alvarado S. 2010. Distribución espacial de rapaces en el Desierto de Atacama, Chile, con notas sobre el Busardo 
de Gurney Buteo poecilochrous. Pp. 153-162. In: Hernández VJ, Muñiz R, Cabot J y de Vries T (Eds.). Aves Rapaces y Conservación. Una perspectiva iberoamericana. Tundra Ediciones, Valencia, España.

Cabot J, de Vries T, Márquez C. 2010. Sobre la especiación del Aguila Mora Geranoaetus melanoleucus y los busardos de cola blanca. Pp. 130-136. In: Hernández VJ, Muñiz R, Cabot J y de Vries T (Eds.). Aves Rapaces y Conservación. Una perspectiva iberoamericana. Tundra Ediciones, Valencia, España.

Cabot J, de Vries T, Stiles FG. 2010. On the distribution and habitat of the Gurney's Buzzard Buteo poecilochrous in Colombia and Ecuador. Pp. 147-152. In: Hernández VJ, Muñiz R, Cabot J y de Vries T (Eds.). Aves Rapaces y Conservación. Una perspectiva iberoamericana. Tundra Ediciones, Valencia, España.

Cabot J, de Vries T. 2009. A new subspecies of Gurney’s Hawk Buteo poecilochrous. Bulletin of the British Ornithologists' Club 129 (3): 149-164.

Cabot J, de Vries T, Stiles FG. 2006. Aberrant distribution records of Cordilleran Buzzard (Hawk) Buteo poecilochrous in Colombia reflect confusión with White-tailed Buzzard (Hawk) B. albicaudatus. Bulletin of the British Ornithologists' Club 126 (1): 65-68.

Cabot J, de Vries T. 2003. Buteo polyosoma and B. poecilochrous are two distinct species. Bulletin of the British Ornithologists' Club 123: 190-207.

Cabot J. 1991. Distribution and hábitat selection of Buteo polyosoma and B. poecilochrous in Bolivia and neighbouring countries. Bulletin of the British Ornithologists' Club 111 (4) : 199-209.

Coello M. 1997. Biología reproductiva y hábitats alimenticias de Buteo poecilochrous en el
Páramo de la Reserva Ecológica Antisana, Ecuador. Tesis de Licenciatura, PUCE, Quito, Ecuador.

DeLay LS, Faaborg J, Naranjo J, Paz SM, de Vries T, Parker P. 1996. Paternal care in co-operative polyandrous Galapagos Hawk.Condor 98: 300-311.

de Macedo H. 1964. Curieux cas de nidification du Buteo poecilochrous Gurney sur Puya raimondii. Oiseau Revue fr. Orn. 34: 200-203.

de Vries T. 2011. Sobre el origen de la poliandria del Gavilán de Galápagos por medio de la selección natural. Nuestra Ciencia, $13: 13-17$.

de Vries T, Black J, Solís C, Hernández C. 1983. La Historia Natural del Curiquingue Phalcoboenus carunculatus en los páramos de Antisana y Cotopaxi, Ecuador. Centro de Publicaciones, PUCE, Quito.

de Vries T. 1976. Prey selection and hunting methods of the Galapagos Hawk Buteo galapagoensis. Le Gerfaut 66: 3-42.

de Vries T. 1975. The breeding biology of the Galapagos Hawk Buteo galapagoensis. Le Gerfaut 65: 29-54.

de Vries T. 1973. The Galapagos Hawk, an ecogeographical study with special reference to its systematic position. Doctoral Thesis, Free University, Amsterdam.

Faaborg J, Parker P, DeLay LS, de Vries T, Paz MS, Naranjo J, Waite T. 1995. Confirmation of co-operative polyandry in the Galapagos Hawk Buteo galapagoensis. Behavioral Ecology and Sociobiology 36: 83-90.

Faaborg J, Bednarz J. 1990. Galapagos and Harris Hawks: Divergent causes of sociality in two raptors. In: Stacey $\mathrm{P}$ y Koenig W (Eds.). Co-operative Breeding in Birds. Cambridge Univ. Press, Cambridge, UK. 
Faaborg J. 1985. Reproductive success and survivorship of the Galapagos Hawk Buteo galapagoensis: potential costs and benefits of co-operative polyandry. Ibis 128: $337-347$.

Faaborg J, de Vries T, Patterson CB, Griffin CR. 1980. Preliminary observations on the occurrence and evolution of polyandry in the Galapagos Hawk (Buteo galapagoensis). Auk 97: 581-590.

Faaborg J, Patterson C. 1980. The characteristics and occurrence of co-operative polyandry. Ibis 123: 477-484.

Fieldsa J, Krabbe N. 1990. The birds of the high Andes. Apollo Books, Svenborg, Denmark.

Jaksic FM, Silva S, Marquet PA, Contreras LC. 1991. Food habits of Gurney's Buzzard in pre-Andean ranges and the high Andean plateau of northernmost Chile. Journal of Raptor Research 25 (4): 116-119.

Jiménez JE ,Jaksic FM. 1990. Diet of Gurney's Buzzard in the puna of northernmost Chile. Wilson Bulletin 102: 344-346.
Kjellén N. 1997. Skuas on the Eurasian tundra; relative occurrence of species, ages and colour phases. Ibis 139: 282-288.

Lehmann FC. 1945. Contribuciones al estudio de la fauna de Colombia. Revista de la Universidad del Cauca. $\mathrm{N}^{\circ}$ 6: 110-114. Popayan, Colombia.

Malan G, Crowe TM, Biggs R, Herholdt JJ. 1997. The social system of the Pale Chanting Goshawk Melierax canorus; monogamy $\mathrm{v}$ polyandry and delayed dispersal. Ibis 139: 313-321.

Muñoz L, Balslev H, de Vries T. 1985. Diversidad de la vegetación en cuatro cuadrantes en el páramo pajonal del Antisana, Ecuador. Publicaciones Museo Ecuatoriano de Ciencias Naturales 4(6): 21-33.

Solís C, Black J. 1985. Anidación de Buteo poecilochrous en Antisana, Ecuador. Revista Geográfica, Quito 21: 133-141. 